\title{
Proximate nutritional, elemental and phytochemical analysis of selected wild edible plants of District Malakand, Pakistan
}

\author{
Muhammad Ibrahim ${ }^{1 *}$, Naveed Akhtar ${ }^{1}$, Sara $^{2}$ and Haji Bahadar ${ }^{3}$ \\ 1. Department of Botany, Islamia College Peshawar, Khyber Pakhtunkhwa-Pakistan \\ 2. Department of Zoology, University of Peshawar, Khyber Pakhtunkhwa-Pakistan \\ 3. Institute of Basic Medical Sciences, Khyber Medical University Peshawar, Peshawar-Pakistan \\ *Corresponding author's email: ibrahim.bot@gmail.com
}

Citation

Muhammad Ibrahim, Naveed Akhtar, Sara and Haji Bahadar. Proximate nutritional, elemental and phytochemical analysis of selected wild edible plants of District Malakand, Pakistan. Pure and Applied Biology. Vol. 10, Issue 3, pp781-788. http://dx.doi.org/10.19045/bspab.2021.100080

\begin{tabular}{llll}
\hline \hline Received: $12 / 09 / 2020$ & Revised: 20/11/2020 & Accepted: 25/11/2020 & Online First: 05/12/2020 \\
\hline
\end{tabular}

\section{Abstract}

The objective of this survey was to examine the nutritional, elemental and phytochemical analyses of selected wild edible species of Disttrict Malakand Khyber Pakhtunkhwa, Pakistan. The selected wild edible species Ammaranthus virdis, Chenopodium album, Malva neglecta, Nasturtium officinale and Rumex dentatus were collected from the study site and were subjected to nutritional, elemental and phytochemical analysis. The results of the present nutritional analysis of these selected wild edible species disclosed that these plants possess proteins, fats, fibers, carbohydrates and caloric energy. The Energy Dispersive X-Rays Analysis (EDX) analysis of powdered plants sample showed that these plants also possess the much needed and fundamental elements of human diet like carbon, oxygen, nitrogen, magnesium, sulfur, potassium, phosphorus, aluminium, calcium, silicon, copper, iron and chlorine. Through the qualitative phytochemical screening, it was noticed that, important phytochemical substances such as steroids, saponins, flavonoids, phenols, alkaloids, glycosides and tannins were there in the methanolic extract of the plants. The study demonstrated that such wild edible plants are the inexpensive and rich source of essential and fundamental nutrients, elements and phytochemicals.

Keywords: Elemental analysis; Nutritional analysis; Pakistan; Wild edible plants

\section{Introduction}

The plants which grow on their own in natural habitats and are used as a food are called wild edible plants (WEPs) [1]. From prehistoric period, human beings are using these WEPs to fulfill their own dietary and dietetic necessities and to gratify their hunger. The consumption of such edible species for nutrition and diet are considered fundamental and central chunk of the values and traditions of the local folks throughout the globe [2]. These wild edible species not only offer chief and complementary nutrients but are also a source of income for the local communities, thus guaranteeing food security. The native people, from their own experiences, have knowledge about the significance and role of such plants in their 
daily diet but are also conscious about the probable well-being and ecological threats [3]. These plants are well acknowledged for their indispensable biochemical and nutritional position as these plants contain a reasonable amount of fibers, fats, proteins, carbohydrates, minerals and vitamins $[4,5]$. From traditional and cultural point of view wild native plants were dynamic sources of minerals and vitamins and always played an important role in times of food scarcity, and were also used as herbal remedies [6]. It was supposed and confirmed about these WEPs that they possess useful elements and its uses have always been a good influence on human health. For this reason, commonly used WEPs were assessed and tested for their nutritional and elemental values $[7,8]$. WEPs are generally known as "Chemical Goldmines" which means that these plants possess phytochemicals which have a favorable impact on human health [9]. Phytochemicals such as carbohydrates, proteins, glycosides, alkaloids, flavonoids, tannins, saponins, phenols, and steroids are known to possess healing properties as well as show physiological activity. Plants are of great importance to the health and food of individuals and communities [10].

\section{Materials and Methods}

\section{Plant species collection}

The collection of WEPs was done from different sites of District Malakand $\left(34.5030^{\circ}\right.$ $\mathrm{N}, 71.9283^{\circ}$ E) during March 2018 to February 2020, and properly identified according to flora of Pakistan and relevant literature [11].

\section{Preparation of samples}

The collected plant materials were thoroughly cleaned with water and then shade dried under shade at $25-30^{\circ} \mathrm{C}$ except for moisture analysis where fresh plant parts were used. The dried samples of different plants were grinded into fine powder in a grind mixer and kept in air tight plastic bottles for further nutritional, elemental and phytochemical analyses $[12,13]$.

\section{Nutritional analysis}

The proximate nutritional analysis of dried, powdered plants samples were carried out according to official methods of analysis (AOAC, 2005) in the laboratory of Agriculture Chemistry, Agriculture University Peshawar, Pakistan [14].

Determination of moisture content

Moisture percentage of fresh plants was calculated by oven-dry method. The plant samples were kept in an oven at $102 \pm 2{ }^{\circ} \mathrm{C}$. The weight loss recorded represents the moisture $\%$.

Moisture content $\%=\frac{\text { Weight of sample }- \text { Weight of oven dried sample }}{\text { Weight of sample }} \times 100$

\section{Determination of crude protein}

Micro kjeldahl method was used to determine the crude proteins in plant samples [14]. The percentage of nitrogen was determined by formula mentioned below:

$$
\begin{gathered}
\mathrm{N} \%=\frac{(\mathrm{S}-\mathrm{B}) \times \mathrm{N} \times 0.014 \times \mathrm{D}}{\text { Weight of sample }} \times 100 \\
\text { Where, } \mathrm{D}=\text { Dilution factor } \\
\mathrm{T}=\text { Titration value }(\mathrm{S}-\mathrm{B}) \\
\mathrm{W}=\text { Weight of sample } \\
0.014=\text { Constant value }
\end{gathered}
$$

Crude protein $\%=\mathrm{N} \times 6.25$ (factor)

\section{Determination of fats}

The fat content was calculated by AOAC Soxhlet extraction technique [14]. The fat contents present in plants can be extracted by petroleum ether at a temperature of $40-60^{\circ} \mathrm{C}$. Formula for fat content is:

Crude fat $(\%)=\frac{\text { weight of fat in sample }}{\text { weight of sample }} \times 100$

\section{Determination of ash content}

Muffle furnace was used to calculate ash content in plants. The sample was kept at 
$600^{\circ} \mathrm{C}$ for 8 hours in furnace according to methods of AOAC [14].

Ash $(\%)=\frac{\text { weight of } \text { Ash }}{\text { weight of samlpe }} \times 100$

Determination of crude fiber: Dried plant sample was mixed with acetone ethanol mix and then AOAC methods were carried out to calculate fibers [14].
Fiber $(\%)=\frac{\text { weight of residue }- \text { weight of ash }}{\text { weight of sample }} \times 100$

\section{Determination of carbohydrates}

Difference method was used to calculate carbohydrates. The total of ash\%, fibers $\%$, proteins $\%$ and fats $\%$ were subtracted from $100 \%$ according to AOAC methods [14]. The formula used is as follow.

Carbohydrates $\%=100-($ Ash $\%+$ Fibers $\%+$ Proteins $\%+$ Crude fats $\%)$

Determination of caloric energy

Caloric energy value in a plant sample was calculated when the sum total of carbohydrates and proteins are multiplied by a factor 4 and that of crude fats by a factor 9 according to official methods of analysis [14].

Total energy $(\mathrm{Kcal} / 100 \mathrm{~g})=($ Crude proteins $\times 4)+($ Carbohydrates $\times 4)+($ Crude fats $\times 9)$

\section{Elemental analysis}

The Energy Dispersive X- Rays Analysis (EDX) of powdered plant samples were carried out at Central Resource Laboratory, University of Peshawar Pakistan. About 2 grams of powdered sample was transferred to a metal pellet using (JEE 420) cello tape and coated with gold by using Vacuum Evaporator (JEOL). The EDX (Inca, 200 Model Oxford Company UK) was attached to Scanning Electron Microscope (SEM) [15].

\section{Phytochemical analysis}

Qualitative analyses of selected plants were carried out to examine various phytochemicals like, glycosides, saponins, tannins phenols, alkaloids and steroids present in the methanolic extract. This was done by using standard methods $[16,17]$.

\section{Statistical analysis}

The proximate nutritional and elemental analysis data was made in triplicates and the values are reported as means \pm standard deviation [18]. The statistical computations were made using Microsoft Excel (version 2016).

\section{Results and Discussion}

Moisture content, ash content, and nutritional analyses of WEPs are represented in (Table 1). Moisture in Nasturtium officinale was $(90.20 \%)$ and the lowest moisture content was found in Amaranthus viridis (81.24\%). The dry matter content was maximum in Amaranthus viridis (18.76\%) and lowest in Nasturtium officinale (9.80\%). The Ash content was found maximum in Chenopodium album (18.90\%) and was found minimum in Rumex dentatus $(16.45 \%)$. The highest value of fibers was observed in Malva neglecta (16.50\%) and lowest value was observed in Rumex dentatus $(12.40 \%)$. The value of crude fats was found maximum in Nasturtium officinale $(3.96 \%)$ and minimum value was found in Malva neglecta $(2.25 \%)$. The crude proteins were found maximum in Rumex dentatus $(11.95 \%)$ and minimum in Nasturtium officinale (6.18\%). The highest value of Carbohydrates was observed in Nasturtium officinale $(58.24 \%)$ and lowest in Malva neglecta $(52.82 \%)$. The result obtained from the caloric value was highest for Rumex dentatus 
(298.75\%) and lowest for Malva neglecta (271.13\%).

The elemental analysis of the selected WEPs are shown (Table 2). The results showed that these wild edible species contain essential elements. These plants are therefore, thought to be a major source of essential elements and can be used as one of the potential and cheap source of essential elements in the human diet. The highest value of carbon was found in Chenopodium album (58.56\%) and lowest value was found in Amaranthus viridis $(49.54 \%)$. The oxygen was found maximum in Nasturtium officinale (36.13\%) and minimum value was found in Chenopodium album (29.24\%). The value of nitrogen was observed maximum in Amaranthus viridis $(6.51 \%)$ and minimum in Nasturtium officinale $(4.72 \%)$. The value of potassium was highest in Chenopodium album (9.37\%) and lowest in Nasturtium officinale (2.62\%). Magnesium was found maximum in Amaranthus viridis $(1.14 \%)$ and minimum in Chenopodium album (0.33\%). The other elements such as aluminium, silicon, phosphorus, sulfur, calcium, chloride, iron and copper were present in small quantity in these WEPs.

Results of the present nutritional and elemental composition of these WEPs are compatible and in line with the studies of earlier workers available in literature. However, some disparities are there which are accredited to prevalent ecological and soil situations in the study area, plants age, period and season for plants collection and uptake of nutrients by the plants from the soil. The results of the nutritional and elemental analysis of Amaranthus viridis are in proximity to the results of Sharma et al. [19], those of Chenopodium album are similar to that of Vinita et al. [20], Malva neglecta to that of Ozer \& Aksoy [21], Nasturtium officinale to that of Shad et al. [22] and the results of Rumex dentatus are similar to the results of Mushtaq et al. [23].

Qualitative analysis of phytochemicals in the selected WEPs are represented in (Table 3). The study showed that these plants also contain important phytochemicals which possess therapeutic activities. The study showed that Malva neglecta contain all the tested plants chemicals like saponins, glycosides, alkaloids, steroids, flavonoids, phenols and tannins. The Amaranthus viridis do not contain glycosides and steroids. Chenopodium album have no glycosides and Nasturtium officinale do not contain glycosides, saponins, tannins and steroids. Rumex dentatus have no steroids in its methanolic extract. The results of the qualitative phytochemical analysis of Amaranthus viridis are similar to the study of Kumari et al. [24], those of Chenopodium album are similar to the study of Pandey \& Gupta [25]. The results of Malva neglecta are compatible with Saleem et al. [26], those of Nasturtium officinale are similar to Mazandarani et al. [27] and the results of Rumex dentatus are compatible with the phytochemical study of Nisa et al. [28]. 
Table 1. Nutritional analysis of selected wild edible plants

\begin{tabular}{|c|c|c|c|c|c|c|c|c|}
\hline Plants Name & MC $(\%)$ & $\mathbf{D M}(\boldsymbol{\%})$ & $\mathbf{A s h} \%$ & Fib $(\%)$ & $\mathbf{C F}(\boldsymbol{\%})$ & $\mathbf{C P}(\boldsymbol{\%})$ & $\mathbf{C a r b}(\boldsymbol{\%})$ & $\mathbf{E V}(\mathbf{K c a l} / \mathbf{1 0 0 g})$ \\
\hline $\begin{array}{c}\text { Ammaranthus virdis } \\
\text { I }\end{array}$ & $81.24 \pm 0.2$ & $18.76 \pm 0.2$ & $16.64 \pm 0.01$ & $15.25 \pm 0.5$ & $2.60 \pm 0.01$ & $7.94 \pm 0.01$ & $57.57 \pm 0.2$ & $285.44 \pm 0.3$ \\
\hline $\begin{array}{c}\text { Chenopodium album } \\
\text { I }\end{array}$ & $85.32 \pm 0.6$ & $14.68 \pm 0.4$ & $18.90 \pm 0.1$ & $13.42 \pm 0.2$ & $3.23 \pm 0.01$ & $9.72 \pm 0.04$ & $54.73 \pm 0.5$ & $291.87 \pm 0.5$ \\
\hline $\begin{array}{c}\text { Malva neglecta } \\
\text { Wallr }\end{array}$ & $82.40 \pm 0.2$ & $17.60 \pm 0.1$ & $18.53 \pm 0.03$ & $16.50 \pm 0.05$ & $2.25 \pm 0.4$ & $9.90 \pm 0.1$ & $52.82 \pm 0.3$ & $271.13 \pm 0.1$ \\
\hline $\begin{array}{c}\text { Nasturtium officinale } \\
\text { W.T. Aiton }\end{array}$ & $90.20 \pm 0.5$ & $9.80 \pm 0.05$ & $16.90 \pm 0.1$ & $14.72 \pm 0.6$ & $3.96 \pm 0.06$ & $6.18 \pm 0.03$ & $58.24 \pm 0.02$ & $293.32 \pm 0.3$ \\
\hline Rumex dentatus L. & $88.30 \pm 0.2$ & $11.70 \pm 0.03$ & $16.45 \pm 0.2$ & $12.40 \pm 0.3$ & $2.83 \pm 0.2$ & $11.95 \pm 0.02$ & $56.37 \pm 0.8$ & $298.75 \pm 0.4$ \\
\hline Mean & 85.492 & 14.508 & 17.484 & 14.458 & 2.974 & 9.138 & 55.946 & 288.102 \\
\hline Median & 85.32 & 14.68 & 16.9 & 14.72 & 2.83 & 9.72 & 56.37 & 291.87 \\
\hline Standard Deviation & 3.798 & 3.798 & 1.142 & 1.595 & 0.656 & 2.180 & 2.198 & 10.605 \\
\hline Standard Error & 1.698 & 1.698 & 0.510 & 0.713 & 0.293 & 0.974 & 0.983 & 4.743 \\
\hline Kurtosis & -2.166 & -2.166 & -2.877 & -0.879 & 0.386 & -0.164 & -0.915 & 1.565 \\
\hline Skewness & 0.152 & -0.152 & 0.580 & -0.082 & 0.797 & 0.190 & -0.624 & -1.224 \\
\hline
\end{tabular}

Key: Percent (\%), Moisture content (MC), Dry matter (DM), Fibers (Fib), Crude fats (CF), Crude proteins (CP), Carbohydrates (Carb), EV (Energy value)

Table 2. Elemental analyses of selected wild edible plants

\begin{tabular}{|c|c|c|c|c|c|c|c|c|c|c|c|c|c|}
\hline Plants Name & $\mathrm{C} \%$ & $\mathbf{0 \%}$ & N\% & Mg\% & $\mathrm{Al} \%$ & $\mathrm{Si} \%$ & $\mathbf{P \%}$ & S\% & $\mathrm{K} \%$ & $\mathrm{Ca} \%$ & $\mathrm{Cl} \%$ & $\mathrm{Fe} \%$ & $\mathrm{Cu} \%$ \\
\hline Amaranthus viridis $L$ & 49.54 & 31.87 & 6.51 & 1.14 & 0.26 & 1.01 & 0.64 & 0.43 & 4.89 & 1.97 & 0.70 & 0.29 & 0.76 \\
\hline $\begin{array}{c}\text { Chenopodium album } \\
I\end{array}$ & 58.56 & 29.26 & - & 0.33 & 0.27 & 0.94 & - & 0.29 & 9.37 & 0.28 & 0.51 & 0.18 & - \\
\hline Malva neglecta Wallr & 52.95 & 34.55 & 0.68 & 0.94 & 0.28 & 0.72 & 0.25 & 0.87 & 3.01 & 4.24 & 0.93 & 0.30 & 0.28 \\
\hline $\begin{array}{c}\text { Nasturtium officinale } \\
\text { W.T.Aiton }\end{array}$ & 51.87 & 36.13 & 4.72 & 0.39 & 0.22 & 0.84 & 0.16 & 0.63 & 2.62 & 0.95 & 1.47 & - & - \\
\hline Rumex dentatus $L$. & 55.02 & 32.75 & - & 0.53 & 0.29 & 1.15 & 0.62 & 0.34 & 8.00 & 0.21 & - & 0.25 & - \\
\hline
\end{tabular}


Ibrahim et al.

\begin{tabular}{|c|c|c|c|c|c|c|c|c|c|c|c|c|c|}
\hline Mean & 53.58 & $\begin{array}{c}32.91 \\
2\end{array}$ & 3.97 & 0.666 & 0.264 & $\begin{array}{c}0.93 \\
2\end{array}$ & 0.4175 & $\begin{array}{c}0.51 \\
2\end{array}$ & 5.578 & 1.53 & 0.9025 & 0.255 & 0.52 \\
\hline Median & 52.95 & 32.75 & 4.72 & 0.53 & 0.27 & 0.94 & 0.435 & 0.43 & 4.89 & 0.95 & 0.815 & 0.27 & 0.52 \\
\hline Standard Deviation & 3.410 & 2.621 & 3.031 & 0.356 & 0.027 & $\begin{array}{c}0.16 \\
3\end{array}$ & 0.284 & $\begin{array}{c}0.23 \\
8\end{array}$ & 3.002 & 1.671 & 0.540 & 0.123 & 0.331 \\
\hline Standard Error & 1.525 & 1.172 & 1.750 & 0.159 & 0.0120 & $\begin{array}{c}0.07 \\
3\end{array}$ & 0.142 & $\begin{array}{c}0.10 \\
6\end{array}$ & 1.342 & 0.747 & 0.270 & 0.061 & 0.234 \\
\hline Kurtosis & 0.251 & -0.231 & 0 & -2.17 & 2.021 & -0.34 & -5.322 & -0.29 & -2.44 & 1.532 & 0.944 & 0.605 & 0 \\
\hline Skewness & 0.569 & -0.280 & -1.05 & 0.605 & -1.338 & $\begin{array}{c}0.05 \\
0\end{array}$ & -0.106 & $\begin{array}{c}0.94 \\
9\end{array}$ & 0.393 & 1.385 & 1.059 & -1.188 & 0 \\
\hline
\end{tabular}

Key: \% (Percentage), C (Carbon), O (Oxygen), N(Nitrogen), Mg (Magnesium), Al (Aluminium), Si (Silicon), P(Phosphorus), S (Sulfur), K (Potassium), Ca (Calcium), $\mathrm{Cl}$ (Chlorine), $\mathrm{Fe}$ (Iron), $\mathrm{Cu}$ (Copper)

\section{Table 3. Qualitative phytochemical analysis of selected wild edible plants}

\begin{tabular}{|c|c|c|c|c|c|}
\hline $\begin{array}{c}\text { Phytochemicals } \\
\text { Alkaloids }\end{array}$ & $\begin{array}{c}\text { Amaranthus virdis } \\
\text { L. }\end{array}$ & $\begin{array}{c}\text { Chenopodium } \\
\text { album L. }\end{array}$ & Malva neglecta Wallr & $\begin{array}{c}\text { Nasturtium officinale } \\
\text { W.T.Aiton }\end{array}$ & Rumex dentatus L. \\
\hline Flavonoids & + & + & + & + & + \\
\hline Glycosides & + & + & + & - & + \\
\hline Phenols & + & - & + & + & + \\
\hline Saponins & + & + & + & - & + \\
\hline Tannins & + & + & + & - & + \\
\hline Steroids & - & + & + & - & + \\
\hline
\end{tabular}

Key: (+) Presence, (-) Absenc 


\section{Conclusion}

The recent research work revealed that WEPs possess latent to offer all the essential nutrients to the human beings. Amaranthus viridis, Chenopodium album, Malva neglecta, Nasturtium officinale and Rumex dentatus were found as excellent basis of fibers, fats, proteins, fats, carbohydrates and energy. These plants were also found to be a useful basis of indispensable elements like as $\mathrm{C}, \mathrm{O}, \mathrm{N}, \mathrm{P}, \mathrm{K}, \mathrm{Mg}, \mathrm{S}, \mathrm{Al}, \mathrm{Si}, \mathrm{Cu}, \mathrm{Fe}, \mathrm{Na}$ and $\mathrm{Cl}$. The phytochemical screening of the extracts of these wild edibles showed the occurrence of important phytochemicals such as phenols, glycosides, saponins, alkaloids, flavonoids, tannins and steroids. Presence of these phytochemicals in WEPs showed that these plants also have high healing potential.

\section{Authors' contributions}

Conceived and designed the experiments: M Ibrahim \& Sara, Performed the experiments: M Ibrahim \& Sara, Analyzed the data: N Akhtar, Contributed materials/ analysis/ tools: $\mathrm{H}$ Bahadar, Wrote the paper: $\mathrm{M}$ Ibrahim.

\section{References}

1. Beluhan S \& Ranogajec A (2010). Chemical composition and non-volatile components of Croatian wild edible mushrooms. Food Chem 124(3): 14351452.

2. Teklehaymanot $\mathrm{T} \&$ Giday $\mathrm{M}$ (2010). Ethnobotanical study of wild edible plants of Kara and Kwego semipastoralist people in Lower Omo River Valley, Debub Omo Zone, SNNPR, Ethiopia. J Ethnobiol Ethnomed 6:23.

3. Uprety Y, Asselin H, Boon EK, Yadav S and Shrestha KK (2010). Indigenous use and bio-efficacy of medicinal plants in the Rasuwa District, Central Nepal. J Ethnobiol Ethnomed 6:3. https://doi.org/10.1186/1746-4269-6

4. Onwordi CT, Ogungbade AM, Wusu AD (2009). The proximate and mineral composition of three leafy vegetables commonly consumed in Lagos, Nigeria. Af J Pure Appl Chem 3: 102-107.

5. Saikia P \& Deka DC (2013). Mineral content of some wild green leafy vegetables of North-East India. J Chem Pharm Res 5: 117-21.

6. Addis G, Urga K \& Dikasso D (2005). "Ethnobotanical study of edible wild plants in some selected districts of Ethiopia. Hum Ecol 33: 83-118.

7. Sekeroglu N, Ozkutlu F, Kara SM \& Ozguven M (2008). Determining of Cadmium and micronutrients in medicinal plants from Turkey. $J$ Sci Food Agric 88:86-89.

8. Kibar B, Temel S (2015). Evaluation of mineral composition of some wild edible plants growing in the eastern Anatolia Region Grasslands of Turkey and consumed as vegetable. J Food Process Preserv. https://doi.org/10.1111/jfpp.12583

9. Farhan H, Rammal H, Hijazi A, Hamad H \& Badran B (2012). Phytochemical screening and extraction of polyphenol from stems and leaves of a Lebanese Euphorbia macrolada schyzoceras Boiss. Ann Biol Res 31: 149-156.

10. Thakur, A \& Rays (2014). Certain medicinal plants of Solanaceae and their alkaloids screening. Int Res. J. Medical Sci 2: 4-6.

11. Ali SI \& Qaiser M Eds. (1993-2015). Flora of Pakistan, Karachi.

12. Meena AK, Bansal P, Kumar S, Rao MM \& Garg VK (2010). Estimation of heavy metals in commonly used medicinal plants: A market basket survey. Environ Monit Assess 170: 657660.

13. Street RA, Kulkarni MG, Stirk WA, Southway C \& Staden VJ (2008). Variation in heavy metals and microelements in South African medicinal plants obtained from street 
markets. Food Addit Contam 25: 953960.

14. AOAC 2005. Official Method of Analysis. $18^{\text {th }}$ Ed. Association of Official Analytical Chemists International, Maryland, USA.

15. Goldstein J (2003). Scanning Electron Microscopy and X-Ray Microanalysis. Springer. ISBN 978-0-306-47292-3.

16. Kokate CK (1999). "Practical Pharmacognosy" 4th edition, Vallabh Prakashan Publication, New Delhi, India, 1999.

17. Trease GE \& Evans WC (2002). Pharmacognosy. $15^{\text {th }}$ Ed. London: Saunders Publishers; pp. 214-393.

18. Steel RG, Torrie JH \& Dickey DA (1997). Principles and procedures of statistics: a biometrical approach. 3rd ed. McGraw Hill Book International Co., Singapore.

19. Sharma N, Gupta P, \& Rao CV (2012). Nutrient content, Mineral content and Antioxidant activity of Amaranthus viridis and Moringa oleifera leaves. Res J Med Plant 6: 253-259.

20. Vinita T, Dhruv A \& Charu A (2019). Phytochemical Screening, proximate and elemental analysis of plant species Curcuma caesia, Curcuma longa and Chenopodium album. Res $J$ Chem Environ 23(9): 113-117.

21. Ozer MO \& Aksoy M (2019). Mineral composition and nutritional properties of Malva neglecta and Malvella sherardiana consumed as vegetable in Central Black Sea Regionof Turkey. Turk J Food Agric Sci 1: 18-23.

22. Shad AA, Shah HU \& Bakht J (2013). Ethnobotanical Assessment and
Nutritive potential of wild food plants. $J$ Anim Plant Sci 23: 92-97.

23. Mushtaq T, Bahadur A, Shah Z, Danish M \& Khalid S (2012). Elemental and Nutritional analysis and Ethnomedicinal study of selected wild edible species of District Swabi, Khyber Pakhtunkhwa. Pak J Pharm Res 5: 4910-4913.

24. Kumari S, Elancheran R \& Devi R (2018). Phytochemical screening, antioxidant, antityrosinase and antigenotoxic potential of Amaranthus viridis extract. Indian J Pharmacol 50: 130-138.

25. Pandey S \& Gupta RK (2014). Screening of nutritional, phytochemical, antioxidant and antibacterial activity of chenopodium album (Bathua). J Pharmacogn Phytochem 3: 1-9.

26. Saleem U, Khalid S, Zaib S, Anwar F, Ahmad B, Ullah I, Zeb A, \& Ayaz M (2019). Phytochemical analysis and wound healing studies on ethno medicinally important plant Malva neglecta Wallr. J Ethnopharmacol DOI: 1.1016/j:jep.2019. 112401.

27. Mazandarani M, Momeji A \& Moghaddam PZ (2013). Evaluation of phytochemical and antioxidant activities from different parts of Nasturtium officinale R.Br. in Mazandaran. Iranian J Plant Physiol 3: 659-664.

28. Nisa H, Kamili AN, Bandh SA, Amin SU, Lone BA \& Parray JA (2013). Phytochemical screening, antimicrobial and antioxidant efficacy of different extracts of Rumex dentatus L. - A locally used medicinal herb of Kashmir Himalaya. Asian Pac J Trop Dis 3: 434440. 